\title{
PENGARUH STRESS KERJA DAN KESEMPATAN PROMOSI TERHADAP KOMITMEN ORGANISASIONAL DAN TURNOVER INTENTION KARYAWAN SAMARINDA POS
}

\author{
Devia Lorensa ${ }^{a}$, Sukisno Slamet Riadi, Dirga Lestari ${ }^{b}$ \\ Magister Manajemen Universitas Mulawarman, Samarinda \\ devialorensa@gmail.com ${ }^{a \rtimes}$, dirga.lestari.as@feb.unmul.ac.id ${ }^{b}$
}

\begin{abstract}
ABSTRAK
Penelitian ini bertujuan untuk menganalisis pengaruh stress kerja dan kesempatan promosi terhadap komitmen organisasional dan turnover intention karyawan samarinda pos. Pengumpulan data dilakukan dengan menggunakan kuisioner. Metode analisis data menggunakan alat analisis struktural equation modeling atau SEM-Smart Pls. Hasil penelitian menunjukan hubungan negatif antara stress kerja terhadap komitmen organisasional, sama dengan yang ditujukan oleh kesempatan promosi dan komitmen organisasional terhadap turnover intention. Lalu variabel yang menunjukan hubungan positif adalah variabel kesempatan promosi dan stress kerja terhadap Turnover Intention.

Kata kunci: Stress kerja, Promosi, Komitmen organisasional, Turnover intention
\end{abstract}

\begin{abstract}
This study aims to analyze the effect of work stress and promotion chance towards organizational commitment and turnover intention of employees in Samarinda pos. Data collection was carried out using questionnaires. The data analysis method uses analysis tools named structural equation modeling (SEMSmart Pls). The result showed that the work stress had a negative impact on organizational commitment, same as promotion chance and organizational commitment that showed negative impacts toward turnover intentions. In contrast, positive impacts are shown by promotion chance towards organizational commitment and work stress toward the turnover intention.

Keywords: Work Stress, Promotion, Organizational Commitment, Turnover Intention
\end{abstract}

\section{PENDAHULUAN}

Perusahaan atau organisasi dapat dikatakan baik, tumbuh dan berkembang adalah perusahaan atau organisasi yang menitik beratkan pada Sumber Daya Manusia untuk menjalankan fungsinya dengan optimal untuk menghadapi perubahan dinamika lingkungan dan persaingan yang terjadi. Untuk mewujudkan hal tersebut, para professional Sumber Daya Manusia harus mengembangkan dan menunjukan kompetensi yang baru untuk mengisi peran dan tanggung jawab karyawan.

Sumber Daya Manusia adalah modal utama organisasi atau perusahaan yang dimana dapat memberikan kontribusi untuk organisasi yang tidak ternilai dalam strategi pencapaian tujuan organisasi (Syamsudin, 2014). Masing-masing karyawan tentu memiliki kepetingan dan juga tujuan yang berbeda dalam menentukan keputusan keinginan untuk masuk dan bergabung dalam suatu perusahaan. Apabila suatu perusahaan memiliki kemampuan untuk menjaga karyawannya untuk tetap tinggal dan membuat karyawan percaya didalam 
perusahaan dengan memberikan bentuk perhatian, maka perusahaan akan menerima timbalbalik dari karyawan berbentuk komitmen yang tinggi oleh karyawan kepada perusahaan.

Bytyqi et al (2010) menganalisis dan menguji hubungan antara stres kerja, kepuasan kerja, dan komitmen organisasi. Penelitian ini menunjukkan bahwa stres kerja berpengaruh positif dan signifikan terhadap kepuasan kerja dan komitmen organisasi. Penelitian ini mengikuti penjabaran komitmen organisasi, yaitu sejauh mana karyawan terlibat dalam organisasi dan keinginan untuk tetap menjadi anggota, yang berisi tentang loyalitas dan kemauan karyawan untuk bekerja secara optimal bagi organisasi tempat karyawan bekerja (Greenberg, 2003). Komitmen tinggi memiliki dampak pada bertahannya karyawan di perusahaan dan menunjukan keberpihakan seorang karyawan pada organisasi atau perusahaan yang mempekerjakannya (Eaton et al, 1992).

Penelitian ini dilakukan di PT Duta Media Kaltim, Samarinda Pos. Samarinda Pos adalah surat kabar harian yang terbit di Samarinda, Kalimantan Timur.Samarinda Pos memiliki turnover dalam 3 tahun terakhir. Dimana data mebuktikan, 6 karyawan mengundurkan diri dari Samarinda Pos per 2017 hingga 2019 lalu. Karyawan tersebut adalah karyawan yang bekerja sebagai karyawan tetap di Samarinda Pos yang menunjukan bahwa mereka memiliki keinginan untuk keluar dari pekerjaannya di Samarinda Pos dan memilih berkarir di bidang lain. Tentu tingginya turnover mengindikasikan adanya komitmen yang rendah oleh karyawan yang bekerja di Samarinda Pos. (Sumber: Laporan HRD Samarinda Pos 2020).

Perusahaan atau organisasi juga harus mengatur Sumber Daya Manusia nya sebaik mungkin untuk mencapai tujuan perusahaan yang efektif. Untuk mencapainya, perusahaan atau organisasi harus selalu melakukan investasi yang terkait dengan penerimaan, pemilihan dan mempertahankan Sumber Daya Manusia yang berkualitas dari waktu kewaktu agar tidak berdampak pada perpindahan karyawan yang biasa dikenal dengan sebutan Turnover.

Komitmen dapat dijabarkan sebagai salah satu aspek yang penting dari filosodi Sumber Daya Manusia. Komitmen organisasi akan mencerminkan respon yang aktif dari karyawan terhadap perusahaan atau organisasi secara keseluruhan (DeMicco \& Reid, 1988). Meyer et al (1993) menunjukan bahwa peningkatan yang ditunjukan oleh komitmen berhubungan dengan meningkatnya produktivitas dan turnover yang semakin rendah. Lee et al (1992) mengungkapkan bahwa komitmen organisasi atau karyawan merupakan prediktor yang akurat bagi voluntary turnover.

Karyawan yang mengalami banyak tekanan didalam pekerjaan akan mengalami stress kerja yang dimana hal tersebut menjadi penentu terhadap tingginya komitmen karyawan (Nursyamsi, 2020). Greenberg (2003) mendefenisikan stres sebagai reaksi-reaksi emosional dan psikologis yang terjadi pada situasi dimana tujuan individu mendapat halangan dan tidak bisa mengatasinya. Saam \& Wahyuni (2014) menjabarkan bahwa stres adalah suatu perasaan ragu terhadap kemampuannya untuk mengatasi sesuatu karena persedian yang ada tidak dapat memenuhi tuntutan kepadanya.

Faktor lain yang dapat dilakukan perusahaan untuk meningkatkan komitmen karyawan terhadap perusahaan adalah dengan menciptakan sistem promosi pengembangan karir yang lebih baik. Penelitian sebelumnya menganalisis dan menguji pengaruh promosi dan komitmen organisasi terhadap turnover intention karyawan (Siwi et al, 2017). Hasil penelitian menunjukkan bahwa promosi jabatan secara parsial tidak berpengaruh signifikan terhadap intensi turnover karyawan. Sedangkan komitmen organisasi secara parsial berpengaruh signifikan terhadap intensi turnover karyawan. Komitmen organisasi dilakukan untuk mencapai tingkat kepuasan karyawan dimana hak dan kewajiban karyawan diatur agar karyawan dapat berpartisipasi dalam perusahaan (Septyawati, 2010). Dimana juga dijelaskan bahwa pengembangan karir merupakan perbaikan pribadi yang dilakukan oleh 
seseorang untuk mencapai suatu rencana atas kebutuhan dan tujuan pegawai dengan peluang karir yang tersedia sekarang atau dimasa yang akan datang (Handoko, 2008).

Tujuan dan manfaat penelitian ini adalah menganalisis pengaruh stress kerja terhadap komitmen organisasional karyawan, kesempatan promosi terhadap komitmen organisasional karyawan, stress kerja terhadap Turnover intention karyawan, kesempatan promosi terhadap Turnover intention karyawan, kesempatan promosi terhadap Turnover intention, stress kerja terhadap turnover intention melalui komitmen organisasional dan menganalisis pengaruh kesempatan promosi terhadap turnover intention samarinda pos melalui komitmen organisasional.

\section{KAJIAN TEORI}

Sebuah studi menganalisis dan meneliti hubungan antara stres kerja, kepuasan kerja, dan komitmen organisasi. Penelitian ini menunjukkan bahwa stres kerja berpengaruh positif dan signifikan terhadap kepuasan kerja dan komitmen organisasi. Studi tersebut juga menjelaskan bahwa meskipun karyawan merasa stres, mereka tetap merasa puas dengan pekerjaannya, dan mereka akan berkomitmen pada organisasi dan sebaliknya. Menurut penelitian tersebut, kepuasan kerja dan komitmen organisasi bukan merupakan parameter mutlak untuk pencapaian tingkat stres kerja yang rendah (Bytyqi et al, 2010). Dalam penelitian lain yang menganalisis dan menguji kepuasan kerja dan komitmen organisasi terhadap turnover intention. Hasil penelitian menunjukkan bahwa komitmen organisasi tidak berhubungan signifikan dengan intensi turnover karyawan yang memiliki nilai probabilitas sebesar 0,007 yang berada di bawah 0,947. Studi ini menunjukkan bahwa komitmen organisasi yang rendah berdampak pada intensi turnover (Tnay et al, 2013).

Park et al (2014) menganalisis perbedaan komitmen karyawan dan turnover intention antara perusahaan yang berserikat dan perusahaan non-serikat. Studi ini menemukan bahwa komitmen karyawan pada perusahaan yang berserikat lebih tinggi daripada komitmen karyawan pada perusahaan non-serikat. Studi ini melihat hal tersebut berdasarkan kesimpulan dari penjelasan penelitian yang mencerminkan pendapatan yang lebih tinggi dari karyawan serikat dan masa kerja yang lebih lama di perusahaan non-serikat. Hasil penelitian tentang korelasi antara komitmen organisasi dengan intensi turnover karyawan menunjukkan bahwa komitmen organisasional memiliki hubungan negatif yang signifikan dengan turnover intention, dengan nilai probabilitas 0,483 lebih besar dari 0,01. Penelitian ini berpendapat bahwa komitmen organisasional memiliki hubungan yang kuat dengan intensi turnover di perusahaan yang memiliki hasil penelitian yang berbeda dengan penelitian sebelumnya (Jehanzeb et al, 2013). Hasil penelitian lainnya menunjukkan bahwa komitmen organisasi memiliki hubungan negatif dan signifikan terhadap intensi turnover karyawan. Penelitian tersebut berasumsi bahwa semakin tinggi komitmen seorang karyawan maka semakin rendah tingkat turnover perusahaan. Begitu pula sebaliknya, semakin rendah komitmen karyawan maka tingkat turnover karyawan di perusahaan semakin tinggi (Newman et al, 2010).

\section{Turnover Intention}

Turnover Intention adalah keadaan karyawan dari suatu organisasi atau perusahaan memiliki rencana untuk meninggalkan organisasi atau perusahaannya (Saeed et al, 2014) atau juga dapat diartikan secara bebas bahwa keinginan berpindah mengacu pada keinginan yang secara sadar dan disengaja untuk meninggalkan organisasi (Tett \& Meyer, 1993). Yang dimaksud dengan turnover intention adalah ketika anggota atau karyawan suatu organisasi mempunyai rencana atau keinginan untuk keluar dari organisasi. Mereka pindah ke 
organisasi lain berdasarkan keinginan atau kondisi mereka dimana mereka tidak puas dengan kinerja karyawannya. Itu bermaksud untuk mengakhiri hubungan kerja. dengan anggota ini.

Dalam karakteristik Turnover Intention, dinyatakan bahwa ketika karyawan tidak puas dengan pekerjaannya dan perusahaan atau organisasi tidak memiliki kepercayaan terhadap karyawan yang bekerja pada perusahaannya, maka Turnover Intention karyawan akan cenderung lebih besar dan durasi dari karyawan dalam pekerjaan itu akan lebih pendek (Pfeffer, 2007). Keinginan karyawan untuk keluar atau Turnover Intention memiliki dua jenis karakteristik berdasarkan pelakunya, jika karyawan memiliki keinginan untuk pindah dari organisasi atau perusahaan saat ini dengan kehendaknya sendiri maka dapat disebut voluntary turnover. Berlaku juga sebaliknya jika perusahaan atau organisasi tidak puas dengan kinerja karyawannya, maka Turnover Intention jenis ini dapat disebut dengan involuntary turnover (Dess \& Shaw, 2001).

Ada tiga hal yang dapat digunakan dalam mengukur tingkat Turnover Intention suatu organisasi (Mobley, 1986) yaitu; kecendrungan individu berpikir untuk meninggalkan organisasi tempat dia bekerja saat ini, kemungkinan individu untuk mencari pekerjaan pada organisasi lain yang dianggap lebih baik, kemungkinan meninggalkan organisasi.

Dalam penelitian ini, indikator yang digunakan untuk mengukur Turnover Intention adalah indikator yang telah ditetapkan. Berikut merupakan 3 indikator yang digunakan dalam penelitian ini (Dess \& Shaw, 2001); (1) Sering berfikir untuk keluar; (2) Kemungkinan mencari pekerjaan baru; (3) Berfikir untuk mengubah pekerjaan.

\section{Komitmen Organisasional}

Komitmen mewakili sejauh mana seseorang mengidentifikasi dirinya sebagai bagian dari organisasi atau perusahaan dan keinginan untuk melanjutkan partisipasi aktif (Eaton et al, 1992). Komitmen juga merupakan upaya untuk mendefinisikan dan melibatkan diri dalam suatu organisasi dan tidak ingin meninggalkannya (Robbins \& Judge, 2007). Komitmen organisasi adalah sejauh mana karyawan terlibat dalam organisasi dan keinginan untuk tetap menjadi anggota, yang mengandung loyalitas dan kemauan karyawan untuk bekerja secara optimal bagi organisasi tempat karyawan bekerja (Greenberg, 2003). Indikator komitmen yang digunakan dalam penelitian ini adalah (Lee et al., 1992); (1) Keinginan kuat untuk tetap menjadi anggota; (2) Keinginan untuk berusaha keras di tempat kerja; (3) Penerimaan nilai-nilai organisasi; (4) Penerimaan tujuan organisasi. Penerimaan karyawan terhadap visi organisasi.

\section{Stress Kerja}

Stres adalah tuntutan-tuntutan eksternal yang mengenai seseorang, misalnya objekobyek dalam lingkungan atau suatu stimulus yang secara objektif adalah berbahaya (Spielberger, 1972). Stress kerja juga dianggap sebagai status yang dialami ketika muncul ketidak cocokan antara tuntutan-tuntutan yang dihadapi dengan kemampuan yang dimiliki (Looker, 2011). Stress Kerja juga dikonseptualilasikan dari beberapa sudut pandang, diantaranya yaitu stress sebagai stimulus dan stress sebagai stimulus-respon (Gibson et al, 1996). Stress sebagai stimulus adalah pendekatan yang dititikberatkan oleh lingkungan. Pendekatan ini memendang stress sebagai konsekuensi dari interaksi antara stimulus lingkungan dengan respon individu.

Pendekatan stimulus-respon mendefinisikan stress sebagai konsekuensi dari interaksi antara stimulus lingkungan dengan respon individu. Stress dipandang bukan hanya sekedar sebuah stimulus atau respon tetapi, merupakan hasil interaksi dari kondisi stimulus lingkungan dan kecendrungan oleh individu untuk memberikan respon. 
Dapat disimpulkan bahwa, Stress Kerja dapat diartikan sebagai adanya kondisi tidak nyaman atau tidak seimbang antara karateristik keperibadian karyawan dengan karakteristik pekerjanya. Dimana, hal ini dapat terjadi pada segala jenis pekerjaan dan adanya beberapa atribut tertentu dapat mempengaruhi daya tahan stress sesorang karyawan atau pekerja. Dapat disimpulkan bahwa, Stress Kerja dapat diartikan sebagai adanya kondisi tidak nyaman atau tidak seimbang antara karateristik keperibadian karyawan dengan karakteristik pekerjanya.

Stres dapat terjadi di semua jenis pekerjaan, dan atribut tertentu dapat mempengaruhi ketahanan stres karyawan atau pekerja. Jika seseorang mengalami stres, dia menunjukkan gejala baik secara fisik, psikologis, dan gejala yang terlihat dan perilaku. Gejala ini juga dapat timbul dan mengalami stres (Robbins, 2010) mengemukakan bahwa individu yang mengalami stres akan menunjukkan gejala- gejala sebagai berikut: 1) fisiologis, seperti perubahan kimiawi dalam tubuh. 2) Psikologis, seperti ketegangan, rasa bosan, cemas, lelah dan tidak berdaya, serta 3) perilaku, seperti kecerobohan, sering menggerakkan kaki, perubahan pola tidur, makan, kecanduan merokok, panik. Indikator Stress Kerja yang digunakan dalam penelitian ini dikemukakan oleh (Ismail et al, 2013) adalah; (1) Ambiguitas peran; (2) Konflik peran; (3) Peran yang berlebihan; (4) Beban kerja.

\section{Promosi}

Promosi adalah pengalihan seseorang ke tingkat pekerjaan yang lebih tinggi, dan kompensasi proses seleksi (Mathis \& Jackson, 2006). Promosi juga dapat meningkatkan pangkat, pangkat, atau posisi seseorang ke tingkat yang lebih baik dan merupakan bagian dari proses perencanaan karier (Edison et al, 2016). Pengertian promosi jabatan adalah memberikan peluang pertumbuhan pribadi, lebih bertanggung jawab, dan meningkatkan status sosial karyawan. Oleh karena itu, individu yang merasa adanya ketentuan promosi merupakan salah satu kepuasan dalam bekerja (Robbins \& Judge, 2007). Promosi mempunyai arti penting bagi perusahaan karena hal itu berarti stabilitas perusahaan dan moral karyawan akan lebih terjamin. Di tempat kerja, seorang karyawan harus mengharapkan peningkatan - peningkatan dalam karirnya.

Promosi merupakan peningkatan jabatan pegawai dari jabatan sebelumnya ke jabatan yang lebih tinggi (Fahmi, 2016). Promosi berarti peningkatan posisi atau peringkat seseorang dari level sebelumnya ke level yang lebih tinggi (Kasmir, 2016). Promosi adalah perubahan dari satu pekerjaan ke pekerjaan lain dengan kondisi yang lebih baik dari segi jabatan dan tanggung jawab Flippo (2002). Jadi yang dimaksud dengan peluang promosi adalah kesempatan yang diberikan kepada karyawan untuk menduduki jabatan atau jabatan yang lebih tinggi dari sebelumnya yang diikuti dengan tanggung jawab yang lebih tinggi. Ada empat karakteristik dimana kesempatan promosi diberikan kepada karyawan (Weng et al, 2010), yaitu: 1) Kemajuan pencapaian karir atau tingkat di mana pekerjaan seseorang saat ini cocok untuk diberikan promosi berdasarkan prestasinya. 2) Pengembangan kemampuan profesional atau di mana seseorang dikatakan memenuhi syarat untuk dipromosikan untuk memperoleh keterampilan dan pengetahuan baru. 3) Kecepatan Promosi, persepsi nilai karyawan, dan kemungkinan promosi. Pertumbuhan remunerasi, atau persepsi karyawan tentang kecepatan, jumlah, dan kemungkinan peningkatan kompensasi. Indikator Promosi (Wahyudi, 2011) adalah sebagai berikut; (1) Loyalitas; (2) Inisiatif; (3) Tingkat Pendidikan / Prestasi Kerja; (4) Pengalaman Kerja / Senioritas. 


\section{PENGEMBANGAN HIPOTESIS}

\section{Pengaruh Stress Kerja terhadap Komitmen Organisasional}

Hubungan antara stres kerja dan komitmen organisasi menunjukkan arah hubungan yang negatif, dimana semakin signifikan stres kerja akan mengakibatkan penurunan atau penurunan kinerja dan komitmen (Nursyamsi, 2020). Terdapat hubungan negatif antara stres kerja dan komitmen organisasi karena karyawan yang memiliki tingkat stres tinggi berimplikasi pada rendahnya komitmen organisasi (Khatibi et al, 2009). Stres kerja berpengaruh negatif terhadap komitmen organisasi. Artinya stres kerja karyawan dapat mempengaruhi persepsi mereka terhadap keselarasan antara tujuan dan nilai individu dengan organisasi atau perusahaan (Velnampy, 2013). Karyawan dengan tingkat stres kerja yang tinggi cenderung lebih berdampak pada niat keluar yang tinggi. Dalam hal ini stres kerja berpengaruh positif terhadap turnover intention.

\section{Pengaruh Kesempatan Promosi terhadap Turnover Intention}

Promosi adalah program yang dirancang untuk pengembangan karir karyawan dalam suatu organisasi. Peluang promosi perusahaan tidak diterapkan di bawah standar referensi yang ada, seperti pendidikan, pengalaman, senioritas, atau kompetensi karyawan. Banyak alasan yang mengatakan bahwa karyawan yang mengundurkan diri dari organisasinya karena tidak mendapatkan kesempatan untuk berpromosi (Kim, 2012) adalah semakin tinggi peluang promosi dapat menurunkan turnover karyawan atau peluang promosi berpengaruh negatif terhadap turnover intention. Studi tersebut menyarankan bahwa pemimpin eksekutif dan manajer harus memahami faktor-faktor yang mendorong pergantian. Mereka perlu mempertimbangkan strategi yang terkait dengan mendukung pengembangan karir karyawan. Seketika, mereka dapat memberikan perencanaan pengembangan karir, pelatihan, dan pengalaman pengembangan dengan tujuan pencapaian organisasi sehingga karyawan cenderung memiliki sikap untuk terus bergabung dengan organisasi.

\section{Pengaruh Stress Kerja terhadap Turnover Intention}

Stres kerja dapat mempengaruhi emosi, proses berpikir, dan kondisi seseorang, baik secara fisik maupun mental. Karyawan yang mengalami stres kerja yang berlebihan berimplikasi pada turnover sukarela (Robbins \& Judge, 2009). Perputaran sukarela adalah keinginan karyawan untuk meninggalkan organisasi secara sukarela karena suatu alasan. Ketika karyawan mengalami tekanan dalam pekerjaannya, karyawan akan merasakan stres yang berlebihan hingga akhirnya keluar dari organisasi. Stres kerja berpengaruh positif pada intensi turnover (McCarthy et al., 2010). Hal tersebut juga membuktikan bahwa karyawan dengan stres kerja tinggi cenderung lebih berdampak langsung terhadap intensi turnover tinggi (Hasan, 2014). Dalam hal ini stres kerja berpengaruh positif terhadap turnover intention.

\section{Pengaruh Kesempatan Promosi terhadap Turnover Intention}

Promosi adalah program yang dirancang untuk pengembangan karir karyawan dalam suatu organisasi. Peluang promosi perusahaan tidak diterapkan di bawah standar referensi yang ada, seperti pendidikan, pengalaman, senioritas, atau kompetensi karyawan. Banyak alasan yang mengatakan bahwa karyawan yang mengundurkan diri dari organisasinya tidak dapat memperoleh kesempatan promosi. Berdasarkan penelitian Kim (2012), semakin tinggi peluang promosi dapat menurunkan tingkat turnover karyawan, atau peluang promosi berpengaruh negatif terhadap turnover intention. Penelitian Kim (2012) menunjukkan bahwa para pemimpin eksekutif dan manajer harus memahami faktor-faktor yang mendorong 
pergantian. Mereka perlu mempertimbangkan strategi yang terkait dengan mendukung pengembangan karir karyawan. Seketika, mereka dapat memberikan perencanaan pengembangan karir, pelatihan, dan pengalaman pengembangan dengan tujuan pencapaian organisasi sehingga karyawan cenderung memiliki sikap untuk terus bergabung dengan organisasi.

\section{Pengaruh Komitmen Organisasional terhadap Turnover Intention}

Penelitian sebelumnya telah menunjukkan bahwa komitmen organisasi berpengaruh negatif terhadap turnover intention perusahaan. Semakin tinggi komitmen karyawan terhadap perusahaan, maka keinginan keluar dari perusahaan akan semakin rendah, begitu pula sebaliknya (Aydogdu \& Asikgil, 2011). Hasil penelitian menunjukkan bahwa komitmen organisasi berpengaruh negatif terhadap intensi turnover karyawan (Jehanzeb et al, 2013). Mirip dengan penelitian yang dilakukan oleh Ahmed et al (2010), hubungan negatif antara komitmen organisasi dan niat untuk meninggalkan karyawan atau turnover intention. Semakin tinggi komitmen organisasi karyawan maka semakin rendah pula keinginan karyawan untuk keluar dari perusahaan atau organisasi tempatnya bekerja.

\section{Pengaruh Stress kerja terhadap Turnover Intention melalui komitmen organisasional}

Penelitian sebelumnya menjelaskan pengaruh stres kerja terhadap turnover intention melalui komitmen organisasi karyawan. Hal tersebut menunjukkan bahwa stres kerja berpengaruh positif terhadap turnover intention perusahaan. Artinya semakin baik atau baik persepsi karyawan terhadap stres kerja dan komitmen keteladanan akan menurunkan intensi turnover karyawan. Mirip dengan penelitian sebelumnya, yang juga menunjukkan hubungan positif yang signifikan antara stres kerja terhadap turnover intention melalui komitmen organisasi pada perusahaan yang bergerak di bidang food and beverage, Seminyak, Bali. Dalam penelitian ini manajemen harus lebih memperhatikan beban kerja agar tidak melebihi kemampuan karyawan yang dapat menyebabkan stres kerja di dalam perusahaan (Pranata \& Netra, 2019).

\section{Pengaruh Kesempatan Promosi terhadap Turnover Intention melalui Komitmen Organisasional}

Penelitian sebelumnya menunjukkan bahwa komitmen yang tinggi akan mengurangi dampak turnover intention. Promosi pekerjaan akan mempengaruhi tingkat komitmen karyawan, yang secara tidak langsung akan mempengaruhi intensi turnover karyawan. Promosi tersebut berdampak pada peningkatan status, hak, penghasilan, dan fasilitas yang diperoleh karyawan (Caesary, Wessiani, \& Santosa, 2012). Hal ini sejalan dengan penelitian yang menunjukkan adanya hubungan antara peluang promosi dengan intensi turnover karyawan melalui komitmen organisasi sebagai variabel intervening pada karyawan RS Panti Nugroho (Kurniadi, 2018).

\section{Kerangka Konseptual dan Hipotesis Penelitian}

Hipotesis dalam penelitian ini, yaitu;

$\mathrm{H}_{1}$ : Stress kerja berpengaruh signifikan terhadap komitmen organisasional karyawan Samarinda Pos.

$\mathrm{H}_{2}$ : Kesempatan promosi berpengaruh signifikan terhadap komitmen organisasional karyawan Samarinda Pos.

$\mathrm{H}_{3}$ : Stress kerja berpengaruh signifikan terhadap turnover intention karyawan Samarinda Pos. 
$\mathrm{H}_{4}$ : Kesempatan promosi berpengaruh signifikan terhadap turnover intention karyawan Samarinda Pos.

$\mathrm{H}_{5}$ : Komitmen organisasional berpengaruh signifikan terhadap turnover intention karyawan Samarinda Pos.

$\mathrm{H}_{6}$ : Stress kerja berpengaruh signifikan terhadap turnover intention samarinda pos melalui komitmen organisasional.

$\mathrm{H}_{7}$ : Kesempatan promosi berpengaruh signifikan terhadap turnover intention samarinda pos melalui komitmen organisasional.

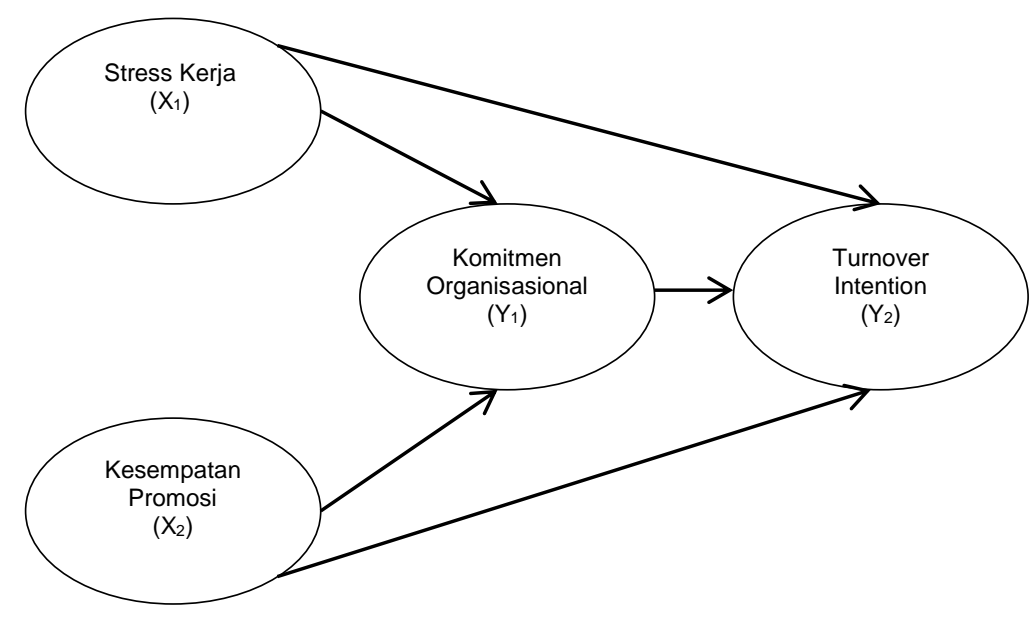

Gambar 1: Kerangka konsep penelitian

Sumber : Data Diolah

\section{METODE PENELITIAN}

Penelitian ini menggunakan penelitian kuantitatif, digunakan untuk meneliti populasi serta sampel yang dilakukan secara terukur, pengumpulan data menggunakan kuesioner, analisis data bersifat statistk untuk menguji hipotesis yang sudah ditetapkan.

\section{Variabel Penelitian}

Variabel-variabel yang digunakan dalam penelitian ini terdiri dari dua kelompok variabel, yaitu variabel endogen atau variabel yang dipengaruhi yang didalam penelitian ini ditunjukan oleh komitmen organisasi dan turover intention $(\mathrm{Y})$ dan penggunaan variabelvariabel eksogen atau variabel yang mempengaruhi yaitu stress kerja dan kesempatan promosi (X).

\section{Populasi dan Sampel}

Populasi dalam penelitian ini adalah seluruh karyawan Samarinda Pos yang berjumlah 59 orang. Dimana didalam jumlah tersebut 41 orang merupakan karyawan tetap Samarinda Pos dengan rincian, 1 orang merupakan direktur utama, 1 orang pemimpin redaksi, 4 orang manajer, 35 karyawan tetap yang terdiri dari editor, jurnais dan wartawan senior dan 18 karyawan kontrak yang menjabat sebagai wartawan dan jurnalis junior staff administrasi pembantu lainnya.

Oleh karena itu, peneliti mengambil seluruh populasi karyawan tetap untuk dijadikan populasi penelitian. Dengan total berjumlah 35 orang karyawan tetap dimana karyawan tersebut merupakan karyawan yang bekerja dibidang jurnalis, wartawan dan editor tidak 
termasuk dalam jajaran direksi, pemimpin redaksi dan juga manajer. Dimana hal tersebut juga telah sesuai dengan data karyawan keluar dimana karyawan yang telah keluar pada 3 tahun terakhir merupakan karyawan yang bergerak dibidang yang telah disebutkan diatas.

Untuk menentukan jumlah sampel penelitian ini, peneliti memakai pedoman yang menyatakan bahwa apabila subjeknya kurang dari 100, lebih baik diambil semua sehingga penelitiannya merupakan penelitian populasi. Selanjutnya, jika jumlah subjeknya besar maka dapat diambil antara 10-15\% atau 20-25\% atau lebih (Ferdinand, 2013).

\section{Metode Pengumpulan Data}

Pengumpulan data yang digunakan dalam penelitian ini adalah kuesioner pribadi. Metode ini menjawab pertanyaan kuesioner, dan dalam penelitian ini kuesioner disebarkan langsung kepada responden. Peneliti dapat memberikan penjelasan yang lugas kepada responden yang kurang memahami pertanyaan dan menjelaskan tujuan survei (Ferdinand, 2013). Penelitian ini mengumpulkan data dengan menyebarkan kuesioner kepada responden; Berikut ini semua karyawan tetap Samarinda Pos. Jawaban responden atas daftar pertanyaan dengan menggunakan skala likert berkisar antara 1 sampai dengan 5 pilihan. Respon paling positif (sangat setuju) adalah skor tertinggi, dan respon paling negatif (sangat tidak setuju) adalah skor terendah (Mas'Ud, 2004).

\section{TEKNIK ANALISIS DATA}

Penelitian ini menggunakan analisis jalur untuk mengetahui hubungan sebab akibat untuk menjelaskan pengaruh langsung dan pengaruh tidak langsung dari sekumpulan variabel sebagai variabel sebab akibat terhadap variabel lain yang merupakan variabel pengaruh. Tujuannya adalah untuk menjelaskan pengaruh langsung dan tidak langsung dari sekumpulan variabel, sebagai variabel penyebab, terhadap variabel lain, yaitu variabel pengaruh.

Analisis data adalah kegiatan mengumpulkan data dari semua responden (dalam penelitian kuantitatif). Analisis data menggunakan analisis jalur untuk menganalisis hubungan antar variabel (Sani \& Maharani, 2013). Model ini bertujuan untuk mengetahui pengaruh langsung atau tidak langsung dari sekumpulan variabel independen (eksogen) terhadap variabel dependen (endogen).

Koefisien jalur adalah koefisien regresi standar; yaitu, koefisien regresi dihitung dari database yang ditetapkan dalam angka standar (Z-score). Dalam melakukan pengujian analisis data untuk model penelitian dalam analisis jalur, berbagai alat dapat digunakan, seperti alat analisis SPSS, AMOS, dan PLS. Sedangkan dalam penelitian ini peneliti menggunakan alat analisis Partial Least Square (PLS) sebagai alat bantu dalam menganalisis data yang ada, dengan syarat uji $\mathrm{F}$ berada pada Alpha $=0,05$ atau $\mathrm{P} \leq 0,05$ sebagai tingkat signifikansi $\mathrm{F}$ (sig. F). Untuk uji-t tingkat signifikansi $=1,96$ atau $\leq 1,96$, digunakan untuk melihat signifikansi pengaruh baik langsung maupun tidak langsung terhadap variabel independen variabel dependen. Adapun teknik analisis data dimaksud dapat diuraikan sebagai berikut.

\section{Analisis Deskriptif}

Salah satu cara agar data dapat dengan mudah dipahami, maka analisis deskriptif adalah salah satu dari bagian statistik yang digunakan. Variabel yang digunakan dalam penelitian ini yaitu stress kerja, kesempatan promosi, komitmen organisasional dan turnover intention. Pengukuran pada variabel diatas menggunakan skor 1 untuk terendah dan 5 untuk skor paling tinggi. Sehingga interval skor tersebut adalah: Interval $=($ Nilai Maksimal - Nilai 
Minimal $) /($ Jumlah Kelas $)=(5-1) / 5=0.8$ (Ghozali, 2016). Berdasarkan pada perhitungan diatas, maka skala distribusi kriteria pendataan adalah sebagai berikut:

Sangat Rendah : $1.00-1.79$

Rendah : $\quad 1.80-2.59$

Cukup : $\quad 2.60-3.39$

Tinggi : $\quad 3.40-4.19$

Sangat Tinggi : $4.20-5.00$

\section{Analisis Inferensial}

Analisis Inferensial adalah merupakan teknik statistik yang digunakan untuk menganalisis data sampel dan menggeneralisasikan hasil populasi, adapun penelitian ini menggunakan alat analisis Partial Least Square (PLS). Perangkat lunak yang digunakan adalah Smart PLS. Wold pertama kali mengembangkan Partial Least Square (PLS) sebagai metode umum untuk mengestimasi model jalur menggunakan konstruksi laten dengan beberapa indikator (Ghozali, 2016). PLS cocok untuk semua skala data (nominal, ordinal, interval, rasio) dan persyaratan asumsi yang lebih fleksibel. PLS juga digunakan untuk mengukur hubungan setiap indikator dengan konstruksinya. Selain itu pada PLS, pengujian bootstrap dapat dilakukan terhadap model struktural yaitu outer model dan inner model.

Penggunaan indikator refleksif dan formatif untuk mengukur setiap konstruknya dalam penelitian ini, dan juga model pengukuran bersifat struktural, serta data berbentuk interval dan rasio, maka diputuskan menggunakan PLS sebagai alat analisis dalam penelitian ini. PLS, selain dapat digunakan untuk mengeksplorasi hubungan antar variabel yang landasan teorinya lemah atau belum ada (berupa pengujian proposisi), maka juga dapat digunakan untuk konfirmasi teori atau pengujian hipotesis (Solimun, 2017). Adapun langkah-langkah PLS dapat dilihat pada Gambar 2.

\section{HASIL PENELITIAN DAN PEMBAHASAN Pengujian Outer Model}

Pengukuran ini menunjukkan bagaimana variabel manifes atau diamati mewakili variabel laten yang akan diukur. Validitas konvergen diukur menggunakan parameter pembebanan luar. Ukuran refleksif individu dapat dikorelasikan jika nilainya lebih dari 0,4 dengan konstruk yang akan diukur (Ghozali, 2016). Dari hasil analisis model pengukuran di atas, terdapat beberapa variabel manifes yang nilai factor loadingnya $<0,4$. Untuk memenuhi aturan praktis, variabel manifes yang nilainya $<0,4$ harus dihapus dari model.

Tabel 1 menunjukkan nilai loading faktor semua variabel manifest $>0.4$, maka tidak ada yang di keluarkan atau di drop. Artinya semua item secara valid mampu merefleksikan masing-masing variabel. Sehingga semua variabel manifest telah memenuhi kaidah - kaidah model pengukuran dan bisa dilanjutkan untuk pengujian selanjutnya. 


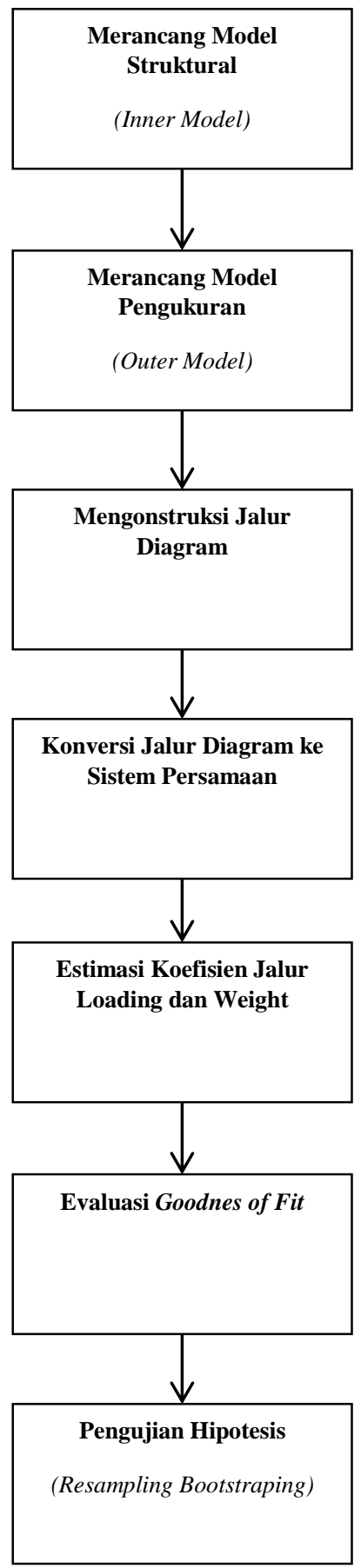

\section{Gambar 2}

Langkah-langkah Partial Least Square (PLS) 
Tabel 1. Pengujian Outer Model

\begin{tabular}{|c|c|c|}
\hline Variabel & Kode & Loading Factor \\
\hline \multirow{4}{*}{ STRESS KERJA } & X1.1 & 0.8983 \\
\hline & $\mathrm{X} 1.2$ & 0.8695 \\
\hline & X1.3 & 0.8414 \\
\hline & X1.4 & 0.6469 \\
\hline \multirow{4}{*}{ KESEMPATAN PROMOSI } & $\mathrm{X} 2.1$ & 0.8418 \\
\hline & $\mathrm{X} 2.2$ & 0.6899 \\
\hline & $\mathrm{X} 2.3$ & 0.7797 \\
\hline & X2.4 & 0.8127 \\
\hline \multirow{4}{*}{ KOMITMEN ORGANISASI } & Y1.1 & 0.8326 \\
\hline & Y1.2 & 0.8284 \\
\hline & Y1.3 & 0.9049 \\
\hline & Y1.4 & 0.8365 \\
\hline \multirow{3}{*}{ TURNOVER INTENTION } & Y2.1 & 0.6962 \\
\hline & Y2.2 & 0.8042 \\
\hline & Y2.3 & 0.8222 \\
\hline
\end{tabular}

Sumber: Olah Data Smart PLS 2020

\section{Uji Reabilitas dan Validitas}

Dalam model pengukuran, uji reliabilitas dilakukan untuk membuktikan keakuratan, konsistensi, dan akurasi instrumen dalam mengukur suatu konstruk. Pada SEM PLS -SE menggunakan SmartPLS, untuk mengukur reliabilitas suatu konstruk dapat dilakukan dengan dua cara yaitu dengan Cronbach's Alpha dan Composite reliability. Namun Cronbach's Alpha untuk menguji reliabilitas suatu konstruk akan memberikan nilai yang lebih rendah (underestimate), sehingga disarankan untuk menggunakan Composite Reliability. Tabel 2 menunjukkan bahwa nilai semua variabel dalam pengujian reliabilitas baik menggunakan Cronbach's Alpha atau Composite Reliability> 0,7. Oleh karena itu, dapat disimpulkan bahwa variabel yang diuji valid dan reliabel untuk menguji model struktural.

Tabel 2. Uji Reliabiltas

\begin{tabular}{|c|c|c|c|}
\hline Variabel & AVE & $\begin{array}{l}\text { Composite } \\
\text { Reliability }\end{array}$ & Cronbachs Alpha \\
\hline Kesempatan promosi & 0.6133 & 0.8632 & 0.7906 \\
\hline Turn Over Intention & 0.6024 & 0.8189 & 0.6669 \\
\hline komitmenorganisasional & 0.7245 & 0.9131 & 0.8731 \\
\hline stress kerja & 0.6723 & 0.8900 & 0.8308 \\
\hline
\end{tabular}

Sumber: Olah Data Smart PLS 2020 


\section{Signifikansi Koefisien Jalur}

Hasil koefisien jalur pada Tabel 3 menunjukkan bahwa semua item signifikan terhadap konstruk dengan nilai at-statistik $>1,96$ dan nilai-p $<0,05$. Dengan demikian, semua item indikator merupakan variabel manifes yang membentuk konstruk Job Stress, Promotion Opportunity, Organizational Commitment, dan Turnover intention.

Tabel 3. Signifikansi Koefisien Jalur

\begin{tabular}{|l|c|c|c|c|c|}
\hline Konstruk & $\begin{array}{c}\text { Original } \\
\text { Sample } \\
(\mathbf{O})\end{array}$ & $\begin{array}{c}\text { Sample } \\
\text { Mean (M) }\end{array}$ & $\begin{array}{c}\text { Standard } \\
\text { Error } \\
\text { (STERR) }\end{array}$ & $\begin{array}{c}\text { T Statistics } \\
\text { (|O/STERR|) }\end{array}$ & P-value \\
\hline X1.1 <- stress kerja & 0.308 & 0.308 & 0.005 & 58.514 & 0.000 \\
\hline X1.2 <- stress kerja & 0.331 & 0.331 & 0.006 & 55.850 & 0.000 \\
\hline X1.3 <- stress kerja & 0.304 & 0.304 & 0.009 & 34.675 & 0.000 \\
\hline X1.4 <- stress kerja & 0.279 & 0.278 & 0.011 & 25.263 & 0.000 \\
\hline $\begin{array}{l}\text { X2.1 <- Kesempatan } \\
\text { promosi }\end{array}$ & 0.346 & 0.346 & 0.007 & 46.676 & 0.000 \\
\hline $\begin{array}{l}\text { X2.2 <- Kesempatan } \\
\text { promosi }\end{array}$ & 0.241 & 0.241 & 0.009 & 27.359 & 0.000 \\
\hline $\begin{array}{l}\text { X2.3 <- Kesempatan } \\
\text { promosi }\end{array}$ & 0.375 & 0.376 & 0.011 & 32.962 & 0.000 \\
\hline $\begin{array}{l}\text { X2.4 <- Kesempatan } \\
\text { promosi }\end{array}$ & 0.307 & 0.307 & 0.007 & 42.365 & 0.000 \\
\hline Y1.1 <- komitmen & 0.289 & 0.289 & 0.006 & 45.874 & 0.000 \\
\hline Y1.2 <- komitmen & 0.247 & 0.247 & 0.005 & 52.215 & 0.000 \\
\hline Y1.3 <- komitmen & 0.335 & 0.335 & 0.006 & 58.995 & 0.000 \\
\hline Y1.4 <- komitmen & 0.300 & 0.300 & 0.007 & 40.437 & 0.000 \\
\hline Y2.1 <- Turn Over & 0.409 & 0.408 & 0.012 & 33.290 & 0.000 \\
\hline Y2.2 <- Turn Over & 0.407 & 0.407 & 0.012 & 34.994 & 0.000 \\
\hline Y2.3 <- Turn Over & 0.472 & 0.472 & 0.014 & 33.045 & 0.000 \\
\hline Sumber: Olah Data & Smart PLS & & & \\
\hline
\end{tabular}

Sumber: Olah Data Smart PLS 2020

\section{R-Square ( $\left.\mathbf{R}^{\mathbf{2}}\right)$}

Tabel 4 menunjukkan bahwa model pengaruh stres kerja dan peluang promosi terhadap komitmen organisasi memberikan nilai 0,61542. Hal tersebut menunjukkan bahwa variabilitas konstruk komitmen organisasi yang dapat dijelaskan oleh variabilitas konstruk stres kerja dan peluang promosi sebesar $61,54 \%$. Model pengaruh stres kerja, peluang promosi, dan komitmen organisasi terhadap turnover memberikan nilai 0,63849. Hal tersebut menunjukkan bahwa variabilitas konstruk turnover yang dapat dijelaskan oleh variabilitas konstruk stres kerja, peluang promosi, dan komitmen organisasi sebesar $63,85 \%$, sedangkan variabel di luar penelitian ini menjelaskan sisanya. 
Tabel 4. Nilai $\mathrm{R}^{2}$

\begin{tabular}{|c|c|}
\hline Endogen Variable & R Square \\
\hline Turnover Intention & 0.63849 \\
\hline Komitmen organisasional & 0.61542 \\
\hline
\end{tabular}

Sumber: Olah Data Smart PLS 2020

\section{Pengaruh Stress Kerja terhadap Komitmen Organisasional}

Stress kerja merupakan respon penyesuaian yang dimediasi oleh perbedaan individu dan proses psikologis, yang merupakan konsekuensi dari setiap tindakan dari luar (lingkungan), situasi, atau kejadian yang menentukan tuntutan psikologis dan fisik yang berlebihan bagi seseorang (Gibson et al, 2011). Hasil uji hipotesis Tabel 5 menunjukkan koefisien jalur sebesar $-0,1627$ dengan nilai mutlak t hitung 5,8376 dan nilai p 0,000. Karena p-value $(0,000)$ lebih kecil dari alpha $5 \%$ maka terdapat pengaruh negatif yang signifikan antara stres kerja terhadap komitmen organisasi. Dengan koefisien -0,1627, semakin tinggi persepsi karyawan terhadap tingkat stres kerja atau semakin tinggi stres kerja maka semakin rendah komitmen organisasi; para karyawan. Sehingga hipotesis yang menyatakan bahwa stres kerja berpengaruh negatif signifikan terhadap komitmen organisasi diterima.

Hasil ini didukung oleh beberapa penelitian diantaranya Hubungan antara stress kerja dan komitmen organisasional menunjukan arah hubungan yang negatif, dimana semakin besar stress kerja akan berakibat pada kinerja dan komitmen yang menurun atau berkurang (Nursyamsi, 2020). Adanya hubungan negatif antara stress kerja dengan komitmen organisasi karena karyawan yang memiliki tingkat stress tinggi berimplikasi terhadap rendahnya komitmen organisasional mereka (Khatibi et al., 2009). Juga dikatakan stress kerja memiliki pengaruh negatif dengan komitmen organisasional. Hal ini dapat diartikan bahwa stress kerja yang dialami oleh karyawan dapat mempengaruhi persepsi mereka terhadap keselarasan antara tujuan dan nilai individu dengan organisasi atau perusahaan. Cha et al. (2011) berpendapat bahwa stress kerja berhubungan negatif dengan komitmen organisasi, karyawan yang memiliki tingkat stress tinggi berimplikasi terhadap rendahnya komitmen organisasional mereka.

Hasil dari sebaran jawaban karyawan terhadap persepsi stress kerja menunjukkan bahwa yang harus diperhatikan manajemen demi mengurangi stres kerja adalah stress dalam bekerja. Oleh karena peran pekerjaan yang terlalu besar hal tersebut karena item pernyataan tersebut memiliki rata-rata tertinggi.

\section{Pengaruh Kesempatan Promosi Terhadap Komitmen Organisasional}

Tabel 5 meunjukkan koefisien jalur sebesar 0.6472, dengan nilai absolut t hitung 26.4536 dan p-value 0.000. Karena p-value $(0,000)$ lebih kecil dari alpha 5\% maka terdapat pengaruh yang signifikan antara peluang promosi dan komitmen organisasi. Koefisien sebesar 0,6472 menunjukkan bahwa semakin tinggi persepsi karyawan terhadap peluang promosi atau semakin tinggi peluang promosi maka komitmen organisasi karyawan akan meningkat. Hipotesis menyatakan bahwa peluang promosi berpengaruh positif signifikan terhadap komitmen organisasi karyawan Samarinda Pos.

Hasil ini didukung oleh beberapa penelitian yang sejalan dengan hal tersebut bahwa perusahaan yang baik adalah perusahaan yang dapat mengelola dan mengembangkan karyawannya dengan baik. Salah satunya adalah pengembangan yang bisa dilakukan oleh perusahaan. Karyawan yang memiliki peluang tinggi untuk memajukan karirnya akan 
memacu motivasi dan komitmennya terhadap perusahaan (Applebaum et al., 2001). Karyawan akan memiliki komitmen yang tinggi terhadap organisasi jika merasakan perlakuan yang adil dalam berkarir, perhatian atasan dengan informasi tentang peluang promosi untuk meningkatkan minat karyawan untuk dipromosikan. Kepuasan karir yang mereka alami selama bekerja tidak diragukan lagi akan membuat karyawan tersebut berkomitmen pada organisasi (Younis et al, 2013).

Hasil analisa deskriptif mendukung penelitian dalam memberikan arahan kepada manajemen faktor apa saja yang harus ditingkatkan terhadap variable kesempatan promosi. Hal yang harus ditingkatkan karena memiliki rata-rata skor terendah adalah Karyawan yang mempunyai tingkat pendidikan yang lebih tinggi, lebih cepat di promosikan, hal tersebut diutamakan. Sedangkan prestasi yang harus dipertahankan oleh manajemen adalah Karyawan yang memiliki pengalaman kerja yang lebih akan di promosikan terlebih dahulu yang artinya karyawan sepakat dengan pernyataan tersebut.

Tabel 5. Hasil Uji Hipotesis

\begin{tabular}{|l|c|c|c|c|c|c|}
\hline Hipotesis & $\begin{array}{c}\text { Original } \\
\text { Sample } \\
(\mathbf{O})\end{array}$ & $\begin{array}{c}\text { Sample } \\
\text { Mean } \\
(\mathbf{M})\end{array}$ & $\begin{array}{c}\text { Standard } \\
\text { Deviation } \\
\text { (STDEV) }\end{array}$ & $\begin{array}{c}\text { Standard } \\
\text { Error } \\
\text { (STERR) }\end{array}$ & $\begin{array}{c}\text { T } \\
\text { Statistics } \\
(\mathbf{O} / \text { STER } \\
\text { R/) }\end{array}$ & P-value \\
\hline $\begin{array}{l}\text { stress kerja -> } \\
\text { komitmen }\end{array}$ & -0.1627 & -0.1625 & 0.0279 & 0.0279 & 5.8376 & 0.0000 \\
\hline $\begin{array}{l}\text { Kesempatan } \\
\text { promosi -> } \\
\text { komitmen }\end{array}$ & 0.6472 & 0.6478 & 0.0245 & 0.0245 & 26.4536 & 0.0000 \\
\hline $\begin{array}{l}\text { stress kerja -> } \\
\text { Turn Over }\end{array}$ & 0.1195 & 0.1201 & 0.0426 & 0.0426 & 2.8035 & 0.0088 \\
\hline $\begin{array}{l}\text { Kesempatan } \\
\text { promosi -> } \\
\text { Turn Over }\end{array}$ & -0.4917 & -0.4903 & 0.0472 & 0.0472 & 10.4089 & 0.0000 \\
\hline $\begin{array}{l}\text { komitmen -> } \\
\text { Turn Over }\end{array}$ & -0.2448 & -0.2456 & 0.0304 & 0.0304 & 8.0425 & 0.0000 \\
\hline $\begin{array}{l}\text { stress kerja -> } \\
\text { komitmen -> } \\
\text { Turn Over }\end{array}$ & 0.03983 & 0.03832 & 0.0084 & 0.0084 & 4.7231 & 0.0000 \\
\hline $\begin{array}{l}\text { Kesempatan } \\
\text { promosi -> } \\
\text { komitmen -> } \\
\text { Turn Over }\end{array}$ & -0.15843 & -0.1591 & 0.0206 & 0.0205 & 7.7026 & 0.000 \\
\hline $\begin{array}{l}\text { Sumber: Olah } \\
\text { Muta }\end{array}$ & & & & & & \\
\hline
\end{tabular}

Sumber: Olah Data Smart PLS 2020

\section{Pengaruh Stress Kerja terhadap Turnover Intention}

Hasil pengujian pda Tabel 5 menunjukkan koefisien jalur sebesar 0.1195, dengan nilai mutlak t hitung 2.8035 dan p-value 0.008 . Karena p-value $(0,008)$ lebih kecil dari alpha 5\% maka terdapat pengaruh positif signifikan stres kerja terhadap turnover intention karyawan di Samarinda Pos. Dengan koefisien sebesar 0.1195, semakin tinggi persepsi karyawan terhadap stres kerja atau semakin tinggi stres kerja maka semakin tinggi intensi turnover karyawan. Sehingga hipotesis yang menyatakan bahwa stres kerja berpengaruh positif signifikan terhadap komitmen organisasi diterima.

Hasil tersebut didukung oleh beberapa penelitian antara lain stres kerja yang dapat mempengaruhi emosi, proses berpikir, dan kondisi seseorang, baik secara fisik maupun mental. Karyawan yang mengalami stres kerja yang berlebihan berimplikasi pada turnover 
sukarela (Robbins \& Judge, 2009). Perputaran sukarela adalah keinginan karyawan untuk meninggalkan organisasi secara sukarela karena suatu alasan. Ketika karyawan mengalami tekanan dalam pekerjaannya, karyawan akan merasakan stres yang berlebihan hingga akhirnya keluar dari organisasi. Stres kerja berpengaruh positif pada intensi turnover (McCarthy et al, 2010). Hal ini juga dibuktikan dalam penelitian (Hasan, 2014), yang membuktikan bahwa karyawan dengan stres kerja tinggi cenderung lebih cenderung berdampak langsung pada kondisi intensi turnover tinggi. Dalam hal ini stres kerja berpengaruh positif terhadap turnover intention.

Hasil dari sebaran jawaban karyawan terhadap persepsi stress kerja menunjukkan bahwa yang harus diperhatikan manajemen demi mengurangi stres kerja adalah stress dalam kerja karena peran pekerjaan yang terlalu besar hal tersebut karena item pernyataan tersebut memiliki rata-rata tertinggi dan hal tersebut akan sangat mempengaruhi turnover intention karyawan samarinda pos, sehingga baik manajemen harus lebih memperhatikan terkait item stress kerja yang akan mampu mencegah meningkatkan turnover intention.

\section{Pengaruh Kesempatan Promosi Terhadap Turnover Intention}

Hasil pengujian hipotesis menunjukkan koefisien jalur sebesar -0,4917, dengan nilai mutlak t hitung 10.4089 dan p-value 0,000 . Karena p-value $(0,000)$ lebih kecil dari alpha 5\% maka terdapat pengaruh yang signifikan antara peluang promosi dan turnover intention. Koefisien sebesar $-0,4917$ artinya semakin tinggi persepsi karyawan terhadap peluang promosi atau semakin tinggi peluang promosi maka semakin rendah intensi turnover karyawan. Hipotesis menyatakan bahwa peluang promosi berpengaruh negatif signifikan terhadap turnover intention karyawan Samarinda Pos.

Beberapa penelitian mendukung hasil tersebut, diantaranya promosi merupakan program yang dirancang untuk pengembangan karir karyawan dalam suatu organisasi. Peluang promosi di perusahaan tidak dilaksanakan berdasarkan standar acuan yang ada, seperti pendidikan, pengalaman, senioritas, atau kompetensi karyawan. Banyak alasan yang mengatakan bahwa karyawan yang mengundurkan diri dari organisasinya tidak dapat memperoleh kesempatan promosi. Mengikuti penelitian Kim (2012), semakin tinggi kesempatan promosi dapat menurunkan intensi turnover karyawan, atau peluang promosi berpengaruh negatif terhadap turnover intention dimana pimpinan eksekutif dan manajer harus memahami faktor-faktor yang mendorong turnover intention. Mereka perlu mempertimbangkan strategi yang terkait dengan mendukung pengembangan karir karyawan. Secara instan mereka dapat memberikan pengalaman perencanaan pengembangan karir, pelatihan dan pengembangan dengan tujuan pencapaian organisasi sehingga karyawan akan cenderung memiliki sikap untuk terus bergabung dengan organisasi.

Hasil analisis deskriptif yang telah dilakukan mendukung penelitian dalam memberikan arahan kepada pihak manajemen faktor-faktor apa saja yang perlu ditingkatkan pada variabel peluang promosi. Hal yang harus ditingkatkan karena yang memiliki nilai ratarata terendah adalah pegawai yang berpendidikan lebih tinggi dipromosikan lebih cepat; ini adalah prioritas perusahaan. Sedangkan prestasi yang harus dijaga oleh manajemen adalah karyawan yang memiliki pengalaman kerja lebih yang akan dipromosikan terlebih dahulu yang artinya karyawan telah setuju dan setuju dengan pernyataan tersebut. Oleh karena itu, manajemen perlu memprioritaskan hal-hal yang harus ditingkatkan dalam hal promosi untuk mengurangi intensi turnover karyawan ke perusahaannya. 


\section{Pengaruh Komitmen Organisasional Terhadap Turnover Intention}

Hasil uji hipotesis menunjukkan bahwa besarnya koefisien path -0.2448 , dengan nilai mutlak t hitung 8.0425 dan p-value 0.000. Karena p-value (0.000) lebih kecil dari alpha 5\% maka artinya terdapat pengaruh yang signifikan antara komitmen organisasi terhadap Turnover intention. Dengan koefisien sebesar -0.2448 dapat diartikan bahwa semakin tinggi atau baik persepsi karyawan terhadap komitmen organisasi atau semakin tinggi komitmen oragnisai maka akan menurunkan Turnover intention karyawan. Sehingga hipotesis yang menyatakan bahwa komitmen organisasu berpengaruh positif signifikan terhadap Turnover intention karyawan samarinda pos diterima.

Hasil tersebut didukung oleh beberapa penelitian diantaranya (Jehanzeb et al, 2013) menunjukan hasil penelitiannya bahwa komitmen organisasional berpengaruh negatif terhadap Turnover Intention karyawan. Sama dengan penilitian yang dilakukan sebelumnya yang juga menyatakan bahwa adanya hubungan negatif antara komitmen organisasi dengan intensi keluar karyawan. Semakin tinggi komitmen organisasi karyawan maka semakin rendang keinginan karyawan untuk keluar dari perusahaan atau organisasi tempat dia bekerja (Ahmed et al, 2010).

Berdasarkan hasil analisa deskriptif, hal yang harus diprioritaskan manajemen dalam meningkatkan komitmen organisasional demi menurunkan Turnover Intention adalah menanamkan nilai nilai perusahaan kepada karyawan agar karyawan makin memiiki rasa komitmen yang tinggi terhadap perusahaan.

\section{Pengaruh stress kerja Terhadap Turnover Intention melalui Komitmen Organisasional}

Hasil uji hipotesis menunjukkan besarnya koefisien path 0.03983 , dengan nilai $t$ hitung 4.7231 dan p-value 0.000. Karena p-value (0.000) lebih kecil dari alpha 5\% maka artinya terdapat pengaruh tidak langsung yang positif signifikan antara stress kerja terhadap turnover intention melalui komitmen organisasional. Dengan koefisien sebesar 0.03983 dapat diartikan bahwa semakin atau baik persepsi karyawan terhadap stress kerja serta memiliki komiten yang baik akan menurunkan turnover intention karyawan samarinda pos. Sehingga hipotesis yang menyatakan bahwa stress kerja sejalan dengan turnover intention posifif signifikan diterima.

Hasil tersebut didukung oleh beberapa penelitian sebelumnya yang bertujuan untuk menjelaskan pengaruh stres kerja terhadap turnover intention melalui komitmen organisasional karyawan menunjukan bahwa stress kerja berpengaruh positif terhadap turnover intention suatu perusahaan (Caesarani \& Riana, 2016). Hal ini dapat diartikan bahwa semakin atau baik persepsi karyawan terhadap stress kerja serta memiliki komiten yang baik akan menurunkan turnover intention karyawan. Sama dengan penelitian sebelumnya dimana dalam penelitian tersebut menyimpulkan bahwa sebaiknya manajemen lebih memperhatikan pembebanan pekerjaan agar tidak melebihi kemampuan karyawan yang dapat mengakibatkan stress kerja didalam perusahaan (Pranata \& Netra, 2019).

\section{Pengaruh kesempatan promosi Terhadap Turnover Intention Melalui Komitmen Organisasional}

Hasil uji hipotesis menunjukkan besarnya koefisien path -0.15843 , dengan nilai t hitung 7.7026 dan p-value 0.000. Karena p-value (0.000) lebih kecil dari alpha 5\% maka artinya terdapat pengaruh tidak langsung yang negatif signifikan antara kesempatan promosi terhadap turnover intention melalui komitmen organisasional. Dengan koefisien sebesar 0.15843 dapat diartikan bahwa semakin atau baik persepsi karyawan terhadap kesempatan promosi serta memiliki komiten yang baik akan menurunkan turnover intention karyawan 
samarinda pos. Sehingga hipotesis yang menyatakan bahwa kesempatan promosi yang dimediasi oleh komitemen organisasional akan menurunkan turnover intention negatif signifikan diterima.

Hasil tersebut didukung oleh penelitian yang telah dilakukan yaitu komitmen yang tinggi akan menurunkan dampak turnover intention oleh (Caesary et al, 2012). Sejalur dengan penelitian yang menunjukan bahwa adanya hubungan antara kesempatan promosi terhadap turnover intention karyawan melalui komitmen organisasional sebagai variabel intervenng pegawai rumah sakit Panti Nugroho (Kurniadi, 2018). Dimana kesempatan promosi jabatan akan mempengaruhi tingkat komitmen karyawan, dimana secara tidak langsung promosi jabatan akan mempengaruhi turnover intention karyawan.

\section{Pembahasan}

Berdasarkan hasil analisis dan pengujian hipotesis yang telah dilakukan pada penelitian ini dapat ditarik beberapa kesimpulan sebagai berikut; (1) Terdapat pengaruh yang negatif signifikan antara stress kerja terhadap komitmen organisasional karyawan samarinda pos. Hasil menunjukan bahwa semakin tinggi persepsi karyawan terhadap tingkat stress kerja atau semakin tinggi stress kerja maka akan menurunkan komitmen organisasional karyawan samarinda pos; (2) Terdapat pengaruh yang positif signifikan antara kesempatan promosi terhadap komitmen organisasional karyawan samarinda pos.

Hasil pengujian menunjukan bahwa semakin tinggi atau baik persepsi karyawan terhadap kesempatan promosi atau semakin tinggi kesempatan promosi maka akan meningkatkan komitmen organisasional karyawan samarinda pos; (3) Terdapat pengaruh yang positif signifikan antara stress kerja terhadap turnover intention karyawan samarinda pos. Hasil menunjukan bahwa semakin tinggi persepsi karyawan terhadap stress kerja atau semakin tinggi stress kerja maka akan meningkatkan turnover intention karyawan samarinda pos; (4) Terdapat pengaruh yang negatif signifikan antara kesempatan promosi terhadap turnover intention karyawan samarinda pos.

Hasil penelitian juga menunjukan bahwa semakin tinggi atau baik persepsi karyawan terhadap kesempatan promosi atau semakin tinggi kesempatan promosi maka akan menurunkan turnover intention pada karyawan samarinda pos; (5) Terdapat pengaruh yang negatif signifikan antara komitmen organisasional terhadap turnover intention karyawan samarinda pos. Hasil menunjukan bahwa semakin tinggi atau baik persepsi karyawan terhadap komitmen organisasional atau semakin tinggi komitmen organisasional maka akan menurunkan turnover intention karyawan samarinda pos; (6) Terdapat pengaruh tidak langsung yang positif signifikan antara stress kerja terhadap turnover intention karyawan samarinda pos melalui komitmen organisasional. Hasil menunjukan bahwa semakin baik persepsi karyawan terhadap stress kerja serta memiliki komitmen organisasional yang baik akan menurunkan turnover intention karyawan khususnya pada karyawan samarinda pos; (7)Terdapat pengaruh tidak langsung yang negatif signifikan antara kesempatan promosi terhadap turnover intention melalui komitmen organisasional karyawan samarinda pos. Hasil menunjukan bahwa semakin atau baik persepsi karyawan terhadap kesempatan promosi serta memiliki komiten yang baik akan menurunkan turnover intention karyawan samarinda pos.

\section{Kesimpulan}

Kesimpulan penelitian ini adalah perlu mempertahankan program terkait kesempatan promosi, karena terbukti secara statsitik merupakan faktor yang paling besar pengaruhnya terhadap komitmen organisasi. Dengan adanya kesempatan promosi mampu meningkatkan meningkatkan komitmen pegawai dalam organisasi. Sedangkan stress kerja menunjukkan 
hasil yang pengaruhnya negative, artinya semakin tinggi tingkat stress kerja akan menurunkan komitmen terhadap organisasional karyawan samarinda pos. Hal tersebut tentunya menjadi masukan yang sangat berharga bagi manajemen dengan kondisi saat ini yang menunjukkan tingkat stress pegawai. Oleh karena itu, dengan menurunkan tingkat stress kerja akan mampu meningkatkan komitmen pegawai terhadap organisasional karyawan samarinda pos.

Berkaitan dengan turnover intention, variabel yang paling besar pengaruhnya adalah tetap kesempatan promosi. Hal tersebut sejalan dengan hasil terhadap komitmen organisasional yang sama-sama memiliki hasil negatif signifikan. Artinya peningkatan kesempatan promosi ternyata tidak hanya berdampak besar terhadap komitmen terhadap organisasional melainkan juga mampu menurunkan turnover intention karyawan samarinda pos.

Berdasarkan kesimpulan yang diperoleh dalam penelitian ini, maka diajukan saransaran bagi Samarinda pos terutama dalam mengurangi turnover intention pada karyawan adalah sebagai berikut:Saran terhadap manajemen demi mengurangi stres kerja adalah memperhatikan tingkat stress dalam kerja karena peran pekerjaan yang harus disesuaikan karena hal tersebut adalah item pernyataan yang memiliki rata-rata tertinggi. Sehingga perlu diperjelas lagi oleh atasan dan perusahaan mengenai batasan-batasan peran kerja yang menjadi tanggung jawab karyawan dalam pekerjaan karen hal tersebut adalah salah satu variabel yang dapat menimbulkan stress kerja.

Untuk meningkatkan kesempatan promosi, maka karyawan yang mempunyai tingkat pendidikan yang lebih tinggi dapat lebih cepat di promosikan. Hal tersebut dapat memotivasi pegawai untuk berkomitemen terhadap perusahaan yang berimplikasi menurunnya turnover intention pada karyawan samarinda pos. Selain itu demi meningkatkan komitmen organisasi dengan menurunkan turnover intention adalah memberikan rasa nyaman dalam perusahaan sehingga karyawan merasa menjadi bagian dari perusahaan dan meningkatkan komitmen yang mereka miliki terhadap perusahaan sehingga mampu menurunkan tingkat turnover intention karyawan samarinda pos.

Untuk variabel turnover intention, manajemen harus memperhatikan kesejahteraan pegawai dari berbagai variabel penyebab yang telah diteliti maupun variabel lain yang dapat dijadikan bahan oleh penulis lain untuk mengurangi tingkat turnover intention karyawan samarinda pos karena hasil kuesioner menunjukkan bahwa pegawai sering berfikir untuk memulai atau membuka bisnis sendiri. Hasil-hasil dalam penelitian ini dan keterbatasanketerbatasan yang ditemukan agar dapat dijadikan sumber ide dan masukan bagi pengembangan penelitian ini dimasa yang akan datang, maka perluasan yang disarankan dari penelitian ini antara lain adalah: menambah variabel independen yang mempengaruhi tingkat turnover intention karyawan samarinda pos.

\section{DAFTAR RUJUKAN}

Ahmed, A., Hussain, I., Shakeel, A., \& Akbar, M. F. (2010). Performance Appraisal Impact on Attitudinal Outcomes and Organizational Performance. International Juornal of Business and Management, 5(10), 62-68.

Applebaum, H. S., Ayre, H., \& Shapiro, B. T. (2001). Career Management in Information Technology: A Case Study. Career Development International, 7(3), 142-158.

Aydogdu, S., \& Asikgil, B. (2011). An empirical study of the relationship among job satisfaction, organizational commitment and turnover intention. International Review of Management and Marketing, 1(3), 43.

Bytyqi, F., Reshani, V., \& Hasani, V. (2010). Work stress, job satisfaction and organizational 
commitment among public employees before privatization. European Journal of Social Sciences, 18(1), 156-162.

Caesarani, A. C., \& Riana, I. G. (2016). Pengaruh stres kerja terhadap komitmen karyawan dan turnover intention pada Sari Segara Resort Villa \& Spa. E-Jurnal Manajemen Universitas Udayana, 5(9).

Caesary, A., Wessiani, N. A., \& B. Santosa. (2012). Analisis Faktor-faktor Yang Mempengaruhi Turnover Intention Pada Agent Outbound Call PT. Infomedia Nusantara Menggunakan Metode Structural Equation Modelling. Jurnal Institut Teknologi Surabaya.

Cha, J. M., Kim, S. H., \& Cichy, R. F. (2011). Job satisfaction, organizational commitment, and contextual performance: Examining effects of work status and emotional intelligence among private club staff members. Psychology \& Marketing, 21(6), 405424.

DeMicco, F. J., \& Reid, R. D. (1988). Older workers: A hiring resource for the hospitality industry. Cornell Hotel and Restaurant Administration Quarterly, 29(1), 56-61.

Dess, G. G., \& Shaw, J. D. (2001). Voluntary turnover, social capital, and organizational performance. Academy of Management Review, 26(3), 446-456.

Eaton, A. E., Gordon, M. E., \& Keefe, J. H. (1992). The impact of quality of work life programs and grievance system effectiveness on union commitment. ILR Review, 45(3), 591-604.

Edison, E., Anwar, Y., \& Komariyah, I. (2016). Manajemen Sumber Daya Manusia. Alfabeta.

Fahmi, I. (2016). Manajemen Sumber Daya Manusia Teori dan Aplikasi. Alfabeta.

Ferdinand, A. (2013). Metode Penelitian Manajemen: Pedoman Penelitian untuk Skripsi, Tesis dan Disertasi Ilmu Manajemen. Badan Penebit Universtas Diponegoro.

Ferdinand, Augusty. (2006). Metode penelitian manajemen. Semarang: Badan Penerbit Universitas Diponegoro.

Flippo, E. B. (2002). Manajemen Personalia (S. Alponso (trans.); 7th ed., Vol. 2). Erlangga.

Ghozali, I. (2016). Aplikasi analisis multivariate dengan program IBM SPSS 23. BPFE Universitas Diponegoro.

Gibson, J., Ivancevich, J., \& Konopaske, R. (2011). Organizations: Behavior, structure, processes. McGraw-Hill Higher Education.

Gibson, J. L., Ivaneevich, J. L., \& Dannelly, J. H. (1996). Organisasi: Perilaku, Struktur, Proses (N. Adriani (trans.)). Binarupa Aksara.

Greenberg, J. (2003). Behavior in Organization (8th ed.). Prentice Hall Inc.

Handoko, T. H. (2008). Manajemen Personalia. BPFE Yogyakarta.

Hasan, R. (2014). Factor Influencing Turnover Intention Among Technical Employees in Information Technology Organization: A Case of XYZ (M) SDN. BHD. International Journal of Arts and Commerce, 3(9).

Ismail, A., Hasan, N. A., Chin, Y.-F. M., Ismail, Y., \& Abu Samah, A. J. (2013). JOB STRESS AS A PREDICTOR OF EMPLOYEE HEALTH. Studies in Business \& Economics, 8(2).

Jehanzeb, K., Rasheed, A., \& Rasheed, M. F. (2013). Organizational commitment and turnover intentions: Impact of employee's training in private sector of Saudi Arabia. International Journal of Business and Management, 8(8), 79-90.

Kasmir. (2016). Manajemen Sumber Daya Manusia. Rajawali Press.

Khatibi, A., Asadi, H., \& Hamidi, M. (2009). The Relationship Between Job Stress and Organizational Commitment in National Olympic and Paralympic Academy. World $J$ Sport Sci, 2. 
Kim, S. (2012). The impact of human resource management on state government IT employee turnover intentions. Public Personnel Management, 41(2), 257-279.

Kurniadi, L. (2018). Pengaruh Promosi Jabatan Dan Stres Kerja Terhadap Turnover Intention Karyawan Dengan Komitmen Sebagai Variabel Intervening Pada Perawat di Rumah Sakit Panti Nugroho Pakem Sleman.

Lee, T. W., Ashford, S. J., Walsh, J. P., \& Mowday, R. T. (1992). Commitment propensity, organizational commitment, and voluntary turnover: A longitudinal study of organizational entry processes. Journal of Management, 18(1), 15-32.

Looker, T. (2011). Manage Your Stress for a Happier Life: Teach Yourself. Hachette UK.

Mas'Ud, F. (2004). Survai Diagnosis Organisasional Konsep dan Aplikasi. In Badan Penerbit Universitas Diponegoro. Badan Penerbit Universitas Diponegoro.

Mathis, R. L., \& Jackson, J. H. (2006). Manajemen Sumber Daya Manusia (10th ed.). Salemba empat.

McCarthy, C. J., Lambert, R. G., Crowe, E. W., \& Colleen McCarthy, J. (2010). Coping, Stress, and Job Satisfaction as Predictors of Advanced Placement Statistics Teachers Intention to Leave the Field. SAGE Publications, 94(4), 306-326.

Meyer, J. P., Allen, N. J., \& Smith, C. A. (1993). Commitment to organizations and occupations: Extension and test of a three-component conceptualization. Journal of Applied Psychology, 78(4), 538.

Mobley, W. H. (1986). Pergantian karyawan: sebab-akibat dan pengendaliannya. Pustaka Binaman Pressindo.

Newman, A., Thanacody, R., \& Hui, W. (2010). The impact of employee perceptions of training on organisational commitment and turnover intentions. A Review of Multinationals in the Chinese Service Sector. 12 (3), 1-21.

Nursyamsi, I. (2020). Pengaruh Kepemimpinan, Pemberdayaan, dan Stres Kerja terhadap Komitmen Organisasional serta dampaknya terhadap kinerja dosen. Conference In Business, Accounting, And Management (CBAM), 1(2), 405-423.

Park, H. Y., Christie, R. L., \& Sype, G. E. (2014). Organizational commitment and turnover intention in union and non-union firms. SAGE Open, 4(1), 2158244013518928.

Pfeffer, J. (2007). Human resources from an organizational behavior perspective: Some paradoxes explained. Journal of Economic Perspectives, 21(4), 115-134.

Pranata, G. D., \& Netra, I. G. S. K. (2019). Pengaruh Stres Kerja Terhadap Turnover Intention Melalui Mediasi Komitmen Organisasional Pada Restoran Queen's Tandoor Seminyak. E-Jurnal Manajemen Universitas Udayana, 8(6), 3531. https://doi.org/10.24843/EJMUNUD.2019.v08.i06.p09

Robbins, S. P., \& Judge, T. (2009). Perilaku Organisasi. Salemba Empat.

Robbins, S.P., \& Judge, T. A. (2007). Perilaku organisasi (10th ed.). PT Indeks Kelompok Gramedia.

Robbins, Stephen P, \& Coulter, M. (2010). Manajemen (B. Sabran \& D. B. Putera (trans.); 10th ed., Vol. 1). Erlangga.

Saam, Z., \& Wahyuni, S. (2014). Psikologi Keperawatan. Raja Grafindo.

Saeed, I., Waseem, M., Sikander, S., \& Rizwan, M. (2014). The relationship of turnover intention with job satisfaction, job performance, leader member exchange, emotional intelligence and organizational commitment. International Journal of Learning and Development, 4(2), 242-256.

Sani, A., \& Maharani, V. (2013). Metodologi Penelitian Manajemen Sumber Daya Manusia: Teori, Kuesioner, dan Analisis Data. Uin Press.

Septyawati, N. (2010). Analisis pengembangan karir pengaruhnya terhadap kepuasan kerja pada kantor pusat PT. Pos Indonesia (PERSERO) Bandung. Jurnal Siasat Bisnis, 3(1), 
$1-15$.

Siwi, G., Taroreh, R. N., \& Dotulong, L. O. H. (2017). Pengaruh Kepuasan Gaji, Promosi Jabata, Komitmen Organisasi terhadap Turnover Intention Karyawan RSU Gmim Pancaran Kasih Manado. Jurnal EMBA: Jurnal Riset Ekonomi, Manajemen, Bisnis Dan Akuntansi, 4(4).

Solimun, Rinaldo Fernandes, Adji Ahmad, \& Nurjannah. (2017). Metode Statistika Multivariat, Pemodelan Persamaan Struktural (SEM) Pendekatan WarpPLS. UB Press.

Spielberger, C. D. (1972). Anxiety Current Trends in Theory and Research. Academic Press. Syamsudin. (2014). Pengaruh Pemberian Insentif Dan Disiplin Kerja Terhadap Kinerja Karyawan Pada PT. Ben Line Agencies (BLA) Banjarmasin. Jurnal Socioscientia, 6(1), $1-44$.

Tett, R. P., \& Meyer, J. P. (1993). Job satisfaction, organizational commitment, turnover intention, and turnover: path analyses based on meta-analytic findings. Personnel Psychology, 46(2), 259-293.

Tnay, E., Othman, A. E. A., Siong, H. C., \& Lim, S. L. O. (2013). The influences of job satisfaction and organizational commitment on turnover intention. Procedia-Social and Behavioral Sciences, 97(201-208), 3-8.

Velnampy, T. (2013). Occupational Stress and Organizational Commitment in Private Banks: A Sri Lankan Experience. Journal of Business Market Management, 5, 254267.

Wahyudi, B. (2011). Manajemen Sumber Daya Manusia. Sulita.

Weng, Q., McElroy, J. C., Morrow, P. C., \& Liu, R. (2010). The relationship between career growth and organizational commitment. Journal of Vocational Behavior, 77(3), 391400.

Younis, N., Akram, A., \& Naseeb, R. A. K. (2013). Career Development and Organizational Commitment: Case study of aPharmaceutical Organization in United Kingdom. International Journal of Scientific and Research Publications, 3(12). 